\title{
Management of Janu Sandhigata Vata with Navaprasrutika Basti - A Case Study
}

\author{
Case Report
}

\section{Shikha Desai1 ${ }^{*}$, Nirmala Sonawane², Mahesh Parappagoudra³, Kritika Thakur1}

1. PG Scholar, 2. Associate Professor, 3. Assistant Professor, Department of Panchakarma, Parul Institute of Ayurved, Parul University, Vadodara, Gujarat.

\begin{abstract}
SandhigataVata may be a disease of the elderly persons. Life style, obesity, trauma and diet deficient in calcium are a number of the risk/causative factors. Rooksha Aahar and Ativyaama cause vitiation of Vata. It mainly affects weight-bearing joints of the body specially knee, hip, lumbar spine. Being commonest variety of articular disorders, SandhigataVata poses a large hindrance in day-to-day activities of the sufferer like walking, dressing and bathing etc. The common presentation of the disease is Shula, Sotha, Vata Poornadriti Sparsha and difficulty in flexion and extension of the Sandhi. Available treatment options include use of NSAID's, calcium supplementation and ultimately joint replacement. Here during this case study, a 36-year-old patient with Janu SandhigataVata came to Parul Ayurved Hospital with complaints of Right knee joint pain, crackling sound in joints since 2 months. Due to long standing and straining, the patient had these symptoms. This Indoor patient was treated with Abhyanga at Nabhi, Parshva, Prushtha \& Ubhaya pada Pradesh and Anuvasana with Murcchit Tila Taila and Navaprasrutik Basti for 10 days. The patient responded well to these Ayurvedic treatments and got relief from major symptoms.
\end{abstract}

Key Words: SandhigataVata, Abhyanga, Anuvasan Basti, Navaprasrutika Basti.

\section{Introduction}

Any disease starts with an absence of proper nutrients or a scarcity of food supply to individual tissues. Nutrients don't enter the target site because of channel blockage- Srotoavarodha. This induces disease at the site of Strotovaigunya. Janu SandhigataVata (Osteoarthritis) is Asthi-Sandhigata Vyadhi, there is Kshaya of Asthi Dhatu because of inadequate supply of Poshaka Rasa. In Ayurveda, Osteoarthritis is related to SandhigataVata. Janu SandhigataVata disorder has been described separately in Charak Samhita. Acharya Charaka explained it under the VataVyadhi chapter. Charaka identified the illness with symptoms like Shotha, Akunchana Prasaranae Vedana, Vatapurna dritiSparsha (1). Acharya Sushruta defined as Shoola (pain), Shotha (swelling), Janu Sandhigata(decreasing of hinge joint movements) as an indication of SandhigataVata (2) due to VataPrakopa arising within the joints and giving rise to symptoms like swelling within the joints (3).

\section{Case Report}

A 36 years old female patient residing in Vadodara city visited Panchakarma-OPD (OPD NO 19034225) of Parul Ayurved Hospital, Vadodara with chief complaints of pain in right knee joint since two months. Before 2 months patient was apparently

\section{* Corresponding Author:}

\section{Shikha Desai}

PG Scholar, Department of Panchakarma,

Parul Institute of Ayurved,

Parul University, Vadodara,

Gujarat. India

Email Id: shikhadesaisd@gmail.com healthy, later she had gradual appearance of abovementioned symptoms and these symptoms lead to difficulty in walking and standing. So patient came to Parul Ayurved Hospital for further management. Patient was admitted in the Panchakarma IPD ward of Parul Ayurved Hospital, for better treatment.

- History of Past illness: No clinical case of Hypertension, Diabetes or Hypothyroidism.

- On Examinations of vitals are Temperature - 98.60 F, Pulse rate $-74 / \mathrm{min}$, Respiratory rate-20/min, Heart rate- $74 / \mathrm{min}$, Blood pressure- $112 / 70 \mathrm{~mm}$ of $\mathrm{Hg}$.

- Rogi Pariksha:- Patients is having Vatapitta Prakriti, predominantly Vatapitta Dosha vitiation is there with involvement of Rasa, asthi, majja, snayu Dusti, moderate Agnibala with niram jivha and Madhyam Vyayama Shakti.

- Systemic Examination: While examining respiratory system the shape and size of chest are normal, Air entry bilaterally equal- clear no Crepitations. While examining Cardiovascular System S1 S2 heard, No murmur and abnormal sounds heard. While examining Central Nervous System Patient was conscious, well oriented, memory was good.

- Gastro Intestinal Tract: Abdomen is soft, no tenderness/Pain was observed.

- Pathology Report:

- $\mathrm{Hb} \%$ : $-11.9 \mathrm{gms} \%$

- RBS: $-121 \mathrm{mg} / \mathrm{dl}$

- Platelet Count: 2.1 lakhs cells/cu mm

- Urine Routine: yellow \& hazy

- PH- 6.0, Specific Gravity - 1.030 
- Radiology Finding

- X -Ray - Changes of OA Grade - I

Table 1: RogiPariksha

\begin{tabular}{|r|l|l|}
\hline 1 & Prakruti & Vata Pitta \\
\hline 2 & Sarata & Madhyam \\
\hline 3 & Sanhananataha & Madhyam \\
\hline 4 & Pramanata & Ht-151cm., Wt-59kg, BMI- 25.87 \\
\hline 5 & Satwataha & Madhyam \\
\hline 6 & Satmytaha & Madhyam \\
\hline 7 & Ahara Shakti & Madhyam \\
\hline 8 & Vyayamataha & Madhyam \\
\hline 9 & Vaya & Madhyam \\
\hline 10 & Jihwa & Nirama \\
\hline 11 & Deshataha & Sadharana \\
\hline
\end{tabular}

Table 2: Systemic Examination-Locomotory System Swelling

Pain

Crepitus

Temperature

- Indicates no symptom; + indicates mild symptoms; ++ indicates moderate symptoms; +++ indicates severe symptoms

Table 3: Samprapti Gataka

\begin{tabular}{|l|l|}
\hline Dosha & VataPradhana \\
\hline Dushya & Asthi. Mamsa,Snayu \\
\hline Srotas & Asthivaha \\
\hline Ama & Niram \\
\hline Udbhavasthana & Pakvashya \\
\hline Vyaktisthana & JanuPradesh \\
\hline
\end{tabular}

\section{Nidana}

- Provisional Diagnosis - Janu sandhigataVata, Ama Vata, Janu Shoola

- Differential Diagnosis -Janu sandhigataVata, Ama Vata, Janu Shoola

- Diagnosis - Janu sandhigataVata

- Prognosis -Sadhya

\section{Treatment (Panchakarma)}

- Abhyanga at Nabhi, Parshva, Prastha, Ubhayapada with Murchhita TilaTaila [10 min].

- Nadi Sweda [3min]

- Anuvashana Basti with Murchhita TilaTaila- [120 $\mathrm{ml}]$.

- Navaprasrutika Basti-As per Schedule.

Table 4: Navaprasrutik Basti Dravyas (4)

\begin{tabular}{|l|l|}
\hline Dravya & Quantity \\
\hline Madhu & $96 \mathrm{ml}$ \\
\hline MoorchitGoghrita & $96 \mathrm{ml}$ \\
\hline MoorchitaTilaTaila & $192 \mathrm{ml}$ \\
\hline BrihatPanchamulakwatha & $480 \mathrm{ml}$ \\
\hline Total quantity & $864 \mathrm{ml}$ \\
\hline
\end{tabular}

\section{Method of administration}

- Form: Anuvashana Basti \& Navaprasrutika Basti

- Dose: AB-120 ml. and NB-864 ml.

- Duration of therapy: For 10days

- Follow up: After $20^{\text {th }}$ days.

Table 5: Kala Basti Schedule

\begin{tabular}{|c|c|c|c|c|c|c|c|c|c|}
\hline DAY1 & DAY2 & DAY3 & DAY4 & DAY5 & DAY6 & DAY7 & DAY8 & DAY9 & DAY10 \\
\hline $\mathrm{AB}$ & $\mathrm{NB}$ & $\mathrm{NB}$ & $\mathrm{NB}$ & $\mathrm{NB}$ & $\mathrm{NB}$ & $\mathrm{NB}$ & $\mathrm{AB}$ & $\mathrm{AB}$ & $\mathrm{AB}$ \\
\hline & $\mathrm{AB}$ & $\mathrm{AB}$ & $\mathrm{AB}$ & $\mathrm{AB}$ & $\mathrm{AB}$ & $\mathrm{AB}$ & & \\
\hline
\end{tabular}

*AB -AnuvasanBasti; *NB-NavaprasrutikBasti

•Diet \& Regimen - Laghu, Supachhya Aahar

Table 6: Chikitsa Protocol

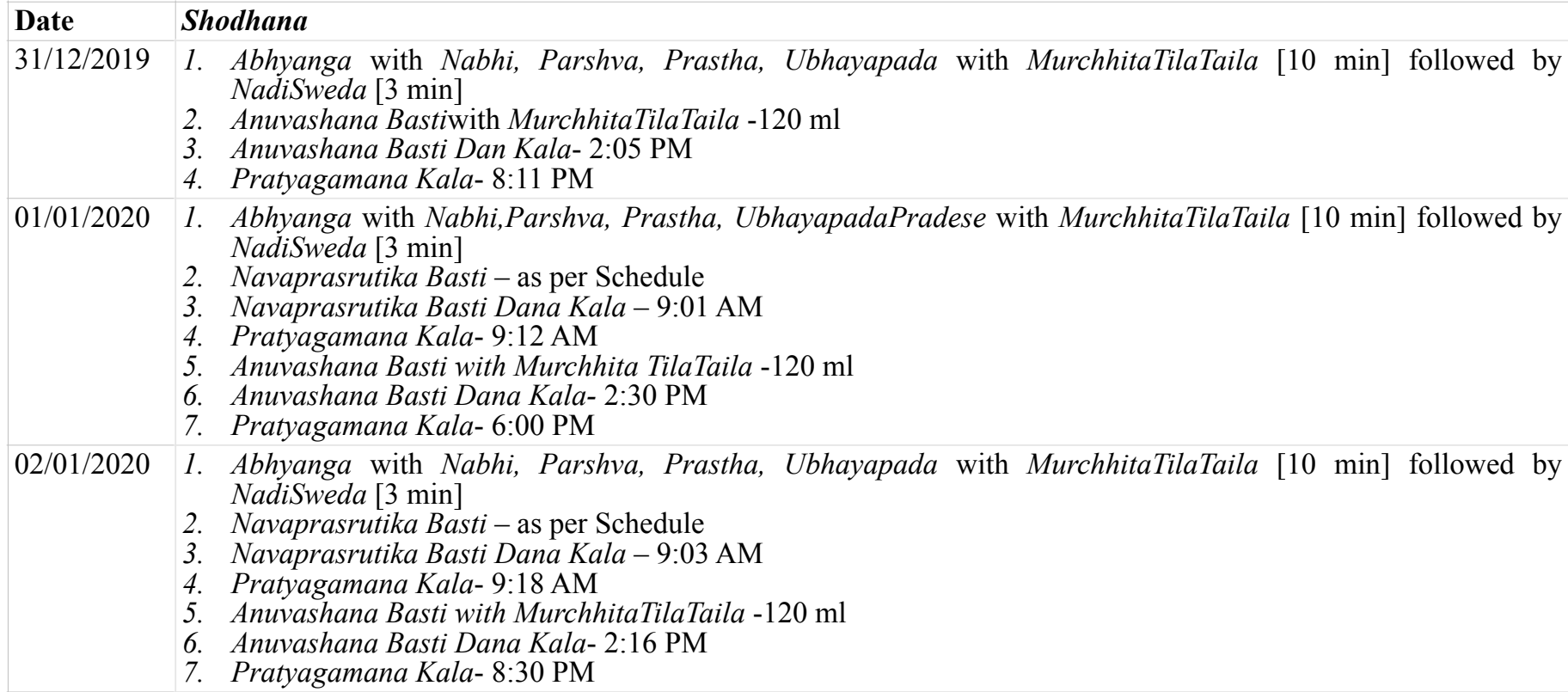


03/01/2020 1. Abhyanga with Nabhi, Parshva, Prastha, Ubhayapada with MurchhitaTilaTaila [10 min] followed by NadiSweda [3 min]

2. Navaprasrutika Basti - as per Schedule

3. Navaprasrutika Basti Dana Kala - 9:16 AM

4. Pratyagamana Kala- 9:24 AM

5. Anuvashana Basti with MurchhitaTilaTaila $-120 \mathrm{ml}$

6. Anuvashana Basti Dana Kala- 2:16 PM

7. Pratyagamana Kala- 8:32 PM

04/01/2020 1. Abhyanga with Nabhi, Parshva, Prastha, Ubhayapada with MurchhitaTilaTaila [10 min] followed by NadiSweda [3 min]

2. Navaprasrutika Basti - as per Schedule

3. Navaprasrutika Basti Dana Kala - 9:12 AM

4. Pratyagamana Kala- 9:30 AM

5. Anuvashana Basti with MurchhitaTilaTaila $-120 \mathrm{ml}$

6. Anuvashana Basti Dana Kala- 2:12 PM

7. Pratyagamana Kala- 8:32 PM

05/01/2020 1. Abhyanga with Nabhi, Parshva, Prastha, Ubhayapada with MurchhitaTilaTaila [10 min] followed by NadiSweda [3 min]

2. Navaprasrutika Basti - as per Schedule

3. Navaprasrutika Basti Dana Kala - 9:02 AM

4. Pratyagamana Kala- 9:20 AM

5. Anuvashana Basti with MurchhitaTilaTaila $-120 \mathrm{ml}$

6. Anuvashana Basti Dana Kala- 2:02 PM

7. Pratyagamana Kala- 9:00 PM

06/01/2020 1. Abhyanga with Nabhi, Parshva, Prastha, Ubhayapada with MurchhitaTilaTaila [10 min] followed by NadiSweda [3 min]

2. Navaprasrutika Basti - as per Schedule

3. Navaprasrutika Basti Dana Kala - 9:05 AM

4. Pratyagamana Kala- 9:19 AM

5. Anuvashana Basti with MurchhitaTilaTaila $-120 \mathrm{ml}$

6. Anuvashana Basti Dana Kala- 2:01 PM

7. Pratyagamana Kala- 9:02 PM

07/01/2020 1. Abhyanga with Nabhi, Parshva, Prastha, Ubhayapada with MurchhitaTilaTaila [10 min] followed by NadiSweda [3 min]

2. Anuvashana Basti with MurchhitaTilaTaila $-120 \mathrm{ml}$

3. Anuvashana Basti Dana Kala- 2:05 PM

4. Pratyagamana Kala- 8:56 PM

08/01/2020 1. Abhyanga with Nabhi, Parshva, Prastha, Ubhayapada with MurchhitaTilaTaila [10 min] followed by NadiSweda [3 min]

2. Anuvashana Basti with MurchhitaTilaTaila $-120 \mathrm{ml}$

3. Anuvashana Basti Dana Kala- 2:02 PM

4. Pratyagamana Kala- 8:32 PM

09/01/2020 1. Abhyanga with Nabhi, Parshva, Prastha, Ubhayapada with MurchhitaTilaTaila [10 min] followed by NadiSweda [3 min]

2. Anuvashana Basti with MurchhitaTilaTaila $-120 \mathrm{ml}$

3. Anuvashana Basti Dana Kala- 2:20 PM

4. Pratyagamana Kala- 9:00 PM

10/01/2020 1. Tab. YogarajGuggulu 2-0-2 with lukewarm water for 20 days After Basti

Shamana 2. Supachhya Ahara

\section{Observations}

Patients underwent the above-mentioned medication from 31/12/2020 to $09 / 01 / 2021$. Patient was assessed before and after treatment.

Table 7: Assessment of symptoms

\begin{tabular}{|l|l|l|l|}
\hline Assessment criteria & Before treatment & After treatment & During Follow-up \\
\hline Pain & Moderate & Occasional pain & No pain \\
\hline Inflammation & - & - & - \\
\hline Tenderness & No Tenderness & No tenderness & No tenderness \\
\hline Crepitation & Moderate Crepitation & Mild Crepitation & No Crepitation \\
\hline
\end{tabular}

SandhigataVata is one of the VataVyadhi mentioned in all of Samhita and Sangraha Granthas. In Ayurvedic view, Sandhis are the seat of Slesamaka Kapha. In SandhigataVata, Vata dosha Prakopa exists in kaphaSthana. Hence, it causes Ruksha guna Vriddhi and Kapha Kshaya. Vata and Kapha are Sheeta in
Guna. Hence, the drug must be Ushna, Brimhana and Anulomana.

\section{Discussion}

Sandhivata could be a disorder dominated by pain affecting the Sandhi (joint). It is caused by morbid 
Vata Dosha. Kapha Dosha may be involved within the clinical presentation. The vitiated Dosha or Doshas afflict the Mamsa, Asthi and Snayu. It is more evident in Asthi Dhatu with which Vayu has Ashraya-Ashrayee Bhava Sambhanda $(5,6,7)$.

As far as Basti goes, it is thought to be an ultimate solution for eradication of Vata Dosha and Vata vitiation. Moreover, it also has action on the vitiated Pitta, Kapha and Rakta. According to Ayurveda, the Virya of ingredients utilized in the Basti gets absorbed and then through general circulation reaches the positioning of lesion and relieves the disease (8). That is why Acharya Sushruta has mentioned that by using the various ingredients, Basti can cure Paittika, Kaphaja, Raktaja, Sansargaja and Sannipatika disorders also (9).

In kala basti, total 16 basti are given. During this procedure, first anuvasana basti was given and followed by 6 niruha and anuvasana basti given alternatively, and at the end again three anuvasna basti were given (10).
Murchita tila taila is indicated in vatavyadhi and Bruhat panchamoola kwatha is beneficial for niruhabasti in vatavyadhi. Navaprasrutikbasti has been classically indicated in vitiated Vata condition and especially in Vata vitiated in Janu pradesha and hence the drug was chosen for present study (11).

Ayurveda gives emphasis on various karmas in treating the foresaid ailment, amongst which Basti Chikitsa is the most effective for Vatadosha, which is the main culprit in sandhivata. All symptoms including joint deformity are mainly due to Vata vitiation. Drugs used here for Basti Karma mainly work on Vatadosha and regulates Vatadosha activity everywhere in the body. Qualities of Bruhat panchamoola are Shothahara (anti-inflamatory), Vatahara (nullifies vatadosha), ushna (hot) etc (12). Some Studies also reported anti inflammatory, analgesic (13), and antipyretic (14), effect of Bruhatpanchamoola.

Table 8: Action of Bruhatapanchamoola

\begin{tabular}{|l|l|l|l|l|l|l|l|}
\hline Sr.No & $\begin{array}{l}\text { Name of } \\
\text { the Drug }\end{array}$ & $\begin{array}{l}\text { BOTANICAL NAME OF } \\
\text { THE DRUG }\end{array}$ & Rasa & Guna & Virya & Vipaka & Karma \\
\hline 1 & Patala & Stereospermum suaveolens DC. & Tikta, Kashaya & $\begin{array}{l}\text { Laghu, } \\
\text { ruksha }\end{array}$ & Anusna & Katu & Tridoshara, sothahara, \\
\hline 2 & Bilva & Aegle marmelos Corr. & $\begin{array}{l}\text { Katu, tikta, } \\
\text { Kashaya }\end{array}$ & $\begin{array}{l}\text { Grahi, } \\
\text { Snigdha, } \\
\text { tikshana }\end{array}$ & $\begin{array}{l}\text { Shothahara, } \\
\text { Arshoghana, } \\
\text { Shirovirechan, }\end{array}$ \\
\hline 3 & Gambhari & Gmelina arborea Linn. & $\begin{array}{l}\text { Tikta, kashya, } \\
\text { Madhur }\end{array}$ & Kathapnopaga
\end{tabular}

Table 9: Symptoms of osteoarthritis may be correlated to SandhigataVata

\begin{tabular}{|l|l|}
\hline \multicolumn{1}{|c|}{ SandhigataVata } & \multicolumn{1}{c|}{ Osteoarthritis } \\
\hline Sandhi shool & Pain within the joints \\
\hline Aatopa & Crepitations within the joints \\
\hline Vedanayuktasandhipravrithi & $\begin{array}{l}\text { Painful movements within the } \\
\text { joints }\end{array}$ \\
\hline Sandhi sthambha & Stiffness within the joints \\
\hline Shotha & Swelling of joints \\
\hline
\end{tabular}

\section{Action of Basti through enteric system (ENS)}

This action is explained in modern parlance by the objection of active principles of drug on receptors within the GI tract associated with the enteric nervous system. ENS (Enteric Nervous System) is substantial group of neurons. It is capable of Autonomous reflex without the influence of central system. Over 500 million neurons are present within the ENS (Enteric Nervous System) so it is called "second brain" (15). There are many similarities between CNS and ENS regarding cellular structure, neuropeptide secretion and specific functions and studies have shown that there is great influence of CNS and ENS on each other (16). Basti may act over the receptors of the ENS to stimulate the CNS causing secretion of required hormones or other chemicals. Hence the effect of Basti may additionally be related to "Touch \& Go Theory" causing activation of ENS receptors. It is recognised that the enteric system nervosum encompasses has a unique ability to mediate reflex activity independently of input from the brain or neural structure (17). This ability implies that the ENS contains sensory receptors, primary afferent neurones, interneurons and motor neurones. The events that are controlled partly by the ENS are multiple and include motor activity, secretion, absorption, blood flow, and interaction with other organs like the gall bladder or pancreas (18). The extensive regulatory activities of the ENS are made possible by the presence and abundance of various varieties of neurones within the wall of the intestines. Morphological, electrophysiological, and pharmacological studies have revealed a considerable substantial diversity of neurones within the ENS (19). It produces a large range of hormones and around 40 
neurotransmitters of the identical classes as those found within the brain. In fact, neurons within the gut are thought to get the maximum amount dopamine as those within the head. Intriguingly, about 95 per cent of the serotonin present within the body at any time is within the ENS. Serotonin produced within the gut gets into the blood, where it is involved in repairing damaged cells within the liver and lungs. It is also important for normal development of the gut, as well as regulating bone density (20).

Purishadhara Kala is nothing but Asthidhara Kala. In the management of Asthivaha Srotodushti, Basti is alluded to as an option of treatment since Basti Dravya will function directly on Pusrishadhara Kala and is required to nourish Asthidhara Kala and Asthidhat specifically (21).

The Basti treatment was chosen for its Vata pacifying property.

The purpose of the administration of Anuvashana or Navaprasrutik Basti was to purify the distribution channels (Srotosodhaka). It improves the straightforward and fast absorption of the given drug and helps it to attain its target (22).

Anuvasana and Navaprasrutik Basti schedules are selected for treatment as this disorder is a component of Madhyama Roga Marga with Gambheera Dhatu i.e. deeper tissue involvement.

Anuvasan Basti was performed for the Poshana of Asthi, Sandhi and its surrounding structures. Navaprasrutik Basti is required to supply strength, compactness, flexibility to the joints of the knee and reinforce Snayu (ligament) and Kandara. In this way, the drug will enter the target tissue and that we can have a direct and long-term effect (23).

\section{Conclusion}

We can conclude that Panchakarma together with oral medication is effective in management of Janu SandhigataVata. Janu SandhigataVata has been seen as an enormous issue in society for an extended time and therefore the risk of incidence is probably going to rise over the approaching years because of this lifestyle. Murchhita TilaTaila Anuvashana Basti and Navaprasrutik Basti has been found to be a powerful Pachaka. And no adverse effects were reported before or after the therapy. During this analysis, we have concluded that Vatahara Ahara Vihara, Ushna, Brihana Dravyas in basti gave relief to the patient.

The patient was treated with Anuvashana and Navaprasrutik Basti. Schedule from 31/12/2020 to $09 / 01 / 2021$ and substantial positive change in signs and symptoms were observed. As very promising findings are obtained during this case study, this may be the main target of additional clinical trials and can offer a chance for debate within the future.

\section{Source of support: Nil}

Conflict of interest: None Declared

\section{References}

1. Vaidya YadavjiTrikamji, Charaka Samhita, Chikitsa by Agniveshaof Chakrapani dutta,Chaukhamba publication, Varanasi Reprint 2017 , Chikitsasthsn28/37Pg617.

2. KavirajaAmbikaduttaShastri, Sushrutasamhitha, nidhanasthanaAyurveda-Tattva - Sandipika $1 / 28-29 \mathrm{Pg} 488$.

3. Vaidya yadavjitrikamjiCharakasamhita. Chikitsasthana byangnivesha of chakrapani duttachaukamba publication varanasi28/37pg 620.

4. Agnivesh, charak Samhita; Samhita; Chakrapanidatta; YadavjiTrikamji, Reprint 2011 Siddhi sthan Chap-8/6 Pg713

5. Prasanna K.G et al: A Brief Case History of Janu SandhigataVataManaged with Ayurveda Treatment] www.ijaar.in : IJAAR VOLUME III ISSUE IV SEP-OCT 2017 Pg 792-795.

6. BhishagacharyaHarishastriParadekara Vidya, Astangahridayam Composed by Hemadri, Choukhamba Orientalia 2002, Varanasi, 9th Edition, Sutra Sthana 11/26Pg186.

7. Gangasahaya Pandey, The Charaka SamhitaOf Agnivesha With Ayurveda Deepika Commentary of Chakrapani Dutta And With 'Vidyotini'Hindi Commentaryby Pt Kashinath Shastri, Chaukhamba Sanskrit Sthana, 1997, Varanasi 5th Edition, Part 2, ChikitsaSthana, 28/12 Pg 778.

8. Gangasahaya Pandey, The Charaka SamhitaOf Agnivesha With Ayurveda Deepika Commentary of Chakrapani Dutta And With 'Vidyotini' Hindi Commentaryby Pt Kashinath Shastri, Chaukhamba Sanskrit Sthana, 1997, Varanasi 5th Edition, Part 2, ChikitsaSthana, 28/15,16,17 Pg779.

9. Agnivesh, charakSamhita; Samhita; Chakrapanidatta; YadavjiTrikamji,Reprint 2011 Siddhi sthanChap-8/6 Pg713

10. Gangasahaya Pandey, The Charaka SamhitaOf Agnivesha With Ayurveda Deepika Commentary Of ChakrapaniduttaAnd With 'Vidyotini'hindi Commentary By Pt Kashinath Shastri, Chaukhamba SanskrithSansthan 1997, 5th Edition, Siddhi Sthana, 1/41 Pg887.

11. Agnivesh, charak Samhita; Samhita;Chakrapanidatta;YadavjiTrikamji, Reprint 2011 Siddhi sthan Chap-1/48 Pg684

12. Vaidya YadavajiTrikamji Acharya, Susrutha Samhita With Nibandhasangraha Commentary of Sri DalhanaAcharya, ChaukhambhaSurbharati Prakashan, Varanasi, Reprint2012, ChikitsaSthana, 35/3Pg 328.

13. Gopal C Nanda1*, R K Tiwari2ayushdhara,Shothahara Activities of DashamoolaDravyas As anAntiInflammatory Formulation with Special Reference to Charak- A Review | January - February 2016 | Vol 3 | Issue 1, 479-485.

14. Gopa 1 C Nanda $1 *$, R K Tiwari, Ayushdhara, Shothahara Activities of Dashamoola Dravyas As an AntiInflammatory Formulation with 
Special Reference toCharak- A Review | January February 2016 | Vol 3 | Issue 1, 479-485.

15. The Second Brain | Our Enteric Nervous System, available from http://www.mfi-therapy.com/ thesecond-brain-our-enteric-nervous-system/(cited on 11 sep 2015)

16. Gut instincts: The secrets of your second brain, available from http://neurosciencestuff.tumblr.com/ post/38271759345/gut-instincts-the-secrets-of-your -second-brain, (cited on 11 sep 2015)

17. Enteric nervous system, available from http:// w w w. s c hol a r p edi a . org/a r t i c l e/ Enteric_nervous_system\#ENS-CNS_interactions (cited on 11 sep 2015)

18. Wood JD. Physiology of the enteric nervous system. In: Johnson LR, ed. Physiology of the gastrointestinal tract, 3rd edn. New York: Raven Press, 1994:423-82.

19. Goyal RK, Hirano I.The enteric nervous system. N Engl J Med 1996,334:1107-15.

20. Furness JB, Costa M. The enteric nervous system. New York: Churchill Livingstone, 1987.

21. Role of Purishdhara Kalacalcicium\& bilirubinmetabolism.Christyjose Cherian Manjeet Singh

22. Priyavratsharma, 28 BastividhiAdhayay Ashtanga SangrahaShrutaSthan28/6Pg 485

23. Agnivesh, charak Samhita; Samhita; Chakrapanidatta; YadavjiTrikamji,Reprint 2011 Siddhi sthan Chap-8/6 Pg713 